\title{
How are oxygen budgets influenced by dissolved iron and growth of oxygenic phototrophs in an iron-rich spring system? Initial results from the Espan Spring in Fürth, Germany
}

\author{
Inga Köhler ${ }^{1}$, Raul E. Martinez ${ }^{2}$, David Piatka ${ }^{1}$, Achim J. Herrmann ${ }^{3}$, Arianna Gallo ${ }^{3}$, Michelle M. Gehringer ${ }^{3}$, and \\ Johannes A. C. Barth ${ }^{1}$ \\ ${ }^{1}$ Department of Geography and Geosciences, GeoZentrum Nordbayern, Schlossgarten 5, \\ Friedrich-Alexander-Universität Erlangen-Nürnberg, 91054 Erlangen, Germany \\ ${ }^{2}$ Organic Paleobiogeochemistry, Max Planck Institute for Biogeochemistry, 07745 Jena, Germany \\ ${ }^{3}$ Division of Microbiology, Technische Universität Kaiserslautern, 67663 Kaiserslautern, Germany
}

Correspondence: Inga Köhler (inga_koehler@gmx.de)

Received: 10 March 2021 - Discussion started: 22 March 2021

Revised: 3 June 2021 - Accepted: 4 June 2021 - Published: 4 August 2021

\begin{abstract}
At present most knowledge on the impact of iron on ${ }^{18} \mathrm{O} /{ }^{16} \mathrm{O}$ ratios (i.e. $\delta^{18} \mathrm{O}$ ) of dissolved oxygen (DO) under circum-neutral conditions stems from experiments carried out under controlled laboratory conditions. These showed that iron oxidation leads to an increase in $\delta^{18} \mathrm{O}_{\mathrm{DO}}$ values. Here we present the first study on effects of elevated $\mathrm{Fe}(\mathrm{II})$ concentrations on the $\delta^{18} \mathrm{O}_{\mathrm{DO}}$ in a natural, iron-rich, circum-neutral watercourse. Our results show that iron oxidation was the major factor for rising dissolved oxygen isotope compositions in the first $85 \mathrm{~m}$ of the system in the cold season (February) and for the first $15 \mathrm{~m}$ during the warm season (May). Further along the course of the stream, the $\delta^{18} \mathrm{O}_{\mathrm{DO}}$ decreased towards values known for atmospheric equilibration around $+24.6 \%$ during both seasons. Possible drivers for these changes may be reduced iron oxidation, increased atmospheric exchange and DO production by oxygenic phototrophic algae mats. In the cold season, the $\delta^{18} \mathrm{O}_{\mathrm{DO}}$ values stabilized around atmospheric equilibrium, whereas in the warm season stronger influences by oxygenic photosynthesis caused values down to $+21.8 \%$ o. In the warm season from $145 \mathrm{~m}$ downstream of the spring, the $\delta^{18} \mathrm{O}_{\mathrm{DO}}$ increased again until it reached atmospheric equilibrium. This trend can be explained by respiratory consumption of DO combined with a relative decrease in photosynthetic activity and increasing atmospheric influences. Our study shows that dissolved $\mathrm{Fe}(\mathrm{II})$ can exert strong effects on the $\delta^{18} \mathrm{O}_{\mathrm{DO}}$ of a natural circum-neutral spring system even under con-
\end{abstract}

stant supply of atmospheric $\mathrm{O}_{2}$. However, in the presence of active photosynthesis, with supply of $\mathrm{O}_{2}$ to the system, direct effects of $\mathrm{Fe}$ oxidation on the $\delta^{18} \mathrm{O}_{\mathrm{DO}}$ value become masked. Nonetheless, critical Fe(II) concentrations may indirectly control DO budgets by enhancing photosynthesis, particularly if cyanobacteria are involved.

\section{Introduction}

Oxygen is the most abundant element $(45.2 \%)$ and iron the fourth most abundant element $(5.8 \%)$ on Earth (Skinner, 1979). Such huge global reservoirs render these elements critically important in global biogeochemical cycles. In addition, their reactivity is exceptional: $\mathrm{O}_{2}$ is a powerful oxidation agent while Fe can cover oxidation states from -4 to +7 in extreme cases, with the most commonly known ones being $0,+2$ and +3 (Lu et al., 2016).

Iron is also an essential trace element in many biological processes, including photosynthesis, oxygen transport and DNA biosynthesis (Kappler et al., 2021). This closely links to the formation and dissolution of Fe oxides. These common forms of metal oxides may enhance or reduce availabilities of both elements in the water column and pore waters and thus may largely regulate aqueous life.

In aqueous environments, dissolved oxygen (DO) is one of the most essential ecosystem parameters, and, despite its 
moderate solubility (e.g. $9.3 \mathrm{mg} \mathrm{L}^{-1}$ at $20^{\circ} \mathrm{C}$ ), it assumes a central role in respiration, primary production and Fe oxidation (Pusch, 1996). The concentration of DO coupled to its stable isotope ${ }^{18} \mathrm{O} /{ }^{16} \mathrm{O}$ ratios (i.e. $\delta^{18} \mathrm{O}$ ) can yield additional information about sources and sinks, including atmospheric input, photosynthesis, respiration and mineral oxidation.

When equilibrated with the atmosphere, $\delta^{18} \mathrm{O}_{\mathrm{DO}}$ values typically range around a value of $+24.6 \%$ (Mader et al., 2017), while photosynthesis and respiration can change these isotope ratios (Guy et al., 1993; Kroopnick, 1975). The splitting of water molecules during photosynthesis hardly produces isotope discrimination, and the resulting DO should have the same isotope value as the surrounding water (Guy et al., 1993; Eisenstadt et al., 2010). Meteoric water in temperate climates is normally depleted in ${ }^{18} \mathrm{O}$, and therefore the photosynthetic oxygen in these areas varies between $-10 \%$ o and $-5 \%$ (Quay et al., 1995; Wang and Veizer, 2000). Respiration, on the other hand, preferentially accumulates ${ }^{16} \mathrm{O}$ and enriches the remaining DO in ${ }^{18} \mathrm{O}$. This process yields $\delta^{18} \mathrm{O}_{\mathrm{DO}}$ values between $+24.6 \%$ and $+40 \%$ (Guy et al., 1993).

Additionally, oxidation of metals such as $\mathrm{Fe}$ also leads to increases in $\delta^{18} \mathrm{O}_{\mathrm{DO}}$ (Lloyd, 1968; Taylor and Wheeler, 1984; Wassenaar and Hendry, 2007; Oba and Poulsen, 2009a, $\mathrm{b}$; Pati, 2016). Mostly, the impacts of Fe oxidation on $\delta^{18} \mathrm{O}_{\mathrm{DO}}$ values have been investigated experimentally under controlled conditions (Oba and Poulson, 2009b; Pati et al., 2016). As a new aspect, these dynamics have not been studied in open water systems such as springs and rivers so far. New field investigations might reconcile variations in the fractionation factors obtained in the above-mentioned studies. Currently they are thought to result from differences in temperature, $\mathrm{pH}$ and initial $\mathrm{Fe}$ (II) concentrations that could be outlined under abiotic conditions.

Dissolved $\mathrm{Fe}$ (II) in natural systems may have primary and secondary impacts on DO concentration and its $\delta^{18} \mathrm{O}_{\mathrm{DO}}$ values. The primary influence originates from the $\mathrm{O}_{2}$ binding by iron oxidation (Eq. 1). This leads to decreases in the DO and causes simultaneous increases in $\delta^{18} \mathrm{O}_{\mathrm{DO}}$ values (Wassenaar and Hendry, 2007; Smith et al., 2011; Parker et al., 2012; Gammons et al., 2014).

$4 \mathrm{Fe}^{2+}+\mathrm{O}_{2}+4 \mathrm{H}^{+} \rightarrow 4 \mathrm{Fe}^{3+}+2 \mathrm{H}_{2} \mathrm{O}$

Dissolved $\mathrm{Fe}$ (II) can also have secondary (i.e. indirect) influences on the DO content and the $\delta^{18} \mathrm{O}_{\mathrm{DO}}$. This happens when it acts as an essential micronutrient to cause growthstimulating effects on $\mathrm{O}_{2}$-producing and respiring microorganisms. These influences of $\mathrm{Fe}(\mathrm{II})$ on $\mathrm{DO}$ and $\delta^{18} \mathrm{O}_{\mathrm{DO}}$ in circum-neutral aquatic systems have so far received little attention because of the following reasons:

1. Fe oxidation often masks $\delta^{18} \mathrm{O}_{\mathrm{DO}}$ values created by respiration, photosynthetic and atmospheric oxygen.
2. Adequate $\mathrm{Fe}(\mathrm{II})$-rich circum-neutral model systems are scarce on modern Earth. This is due to the high reactivity of iron with DO.

To the best of our knowledge, no study so far has systematically investigated the influences of elevated $\mathrm{Fe}$ (II) concentrations on $\delta^{18} \mathrm{O}_{\mathrm{DO}}$ values in a natural and circum-neutral iron-rich system. In order to bridge this gap, we investigated the aqueous chemistry and $\delta^{18} \mathrm{O}_{\mathrm{DO}}$ values in the iron-rich Espan Spring in Fürth, Germany (Fig. 1). This Fe(II)-rich artesian spring offers a complex biogeochemical natural field site to analyse effects of different $\mathrm{Fe}(\mathrm{II})$ contents on the DO and $\delta^{18} \mathrm{O}_{\mathrm{DO}}$ values.

The aims of this study were to establish an inventory of biology together with Fe and oxygen budgets in this natural spring and stream system. We further aimed to investigate how increased Fe(II) levels influence the oxygen budget of the system and whether a combination of DO and $\delta^{18} \mathrm{O}_{\mathrm{DO}}$ measurements can help to assess this effect. This is also timely because environmental impacts of Fe(II) are becoming increasingly recognized for their negative effects on ecosystems such as with the browning or brownification phenomenon (Kritzberg and Ekström, 2012; Weyhenmeyer et al., 2014; Kritzberg et al., 2020). During this process, increased iron levels can consume oxygen, cause algae blooms and reduce water quality and thus may affect aqueous ecosystems and their services. Here we describe a first complete spatial sampling campaign in the cold and warm season with $\mathrm{Fe}(\mathrm{II}), \mathrm{Fe}(\mathrm{III}), \mathrm{DO}$ and its stable ${ }^{18} \mathrm{O} /{ }^{16} \mathrm{O}$ isotope ratios together with field parameters ( $\mathrm{pH}, T$, DO, pe, electrical conductivity). This study contributes to the knowledge of Fe oxidation in natural systems and delivers implications of hardly explored seasonal dynamics in $\mathrm{Fe}(\mathrm{II})$-rich systems.

\section{Methods}

\subsection{Study site}

The Espan Spring is located in the city of Fürth, Germany $\left(49^{\circ} 28^{\prime} 15.8^{\prime \prime} \mathrm{N}, 11^{\circ} 00^{\prime} 53.0^{\prime \prime} \mathrm{E}\right.$; Fig. 1). It is an artesian spring that originates from a confined aquifer that was tapped by a drilling project in 1935 from a depth of $448.5 \mathrm{~m}$ below ground. The water originates from the so-called "lower mineral water horizon". This horizon is dominated by artesian inflow from the lower Buntsandstein Formation. The Buntsandstein in Fürth consists of red sandstone layers that are composed of light reddish to yellowish-white-grey sandstones of different grain sizes. The sandstones are intercalated with various rubble, conglomerate and clay layers as well as thin gypsum and salt (Birzer, 1936). Three noticeable conglomerate layers are present in the sequence of Buntsandstein layers. Birzer (1936) distinguished the Upper Buntsandstein from the Upper Main Buntsandstein by the Main Conglomerate which can be found at a depth of 321 to $324 \mathrm{~m}$. The Middle Boulder Layer at a depth of 370 

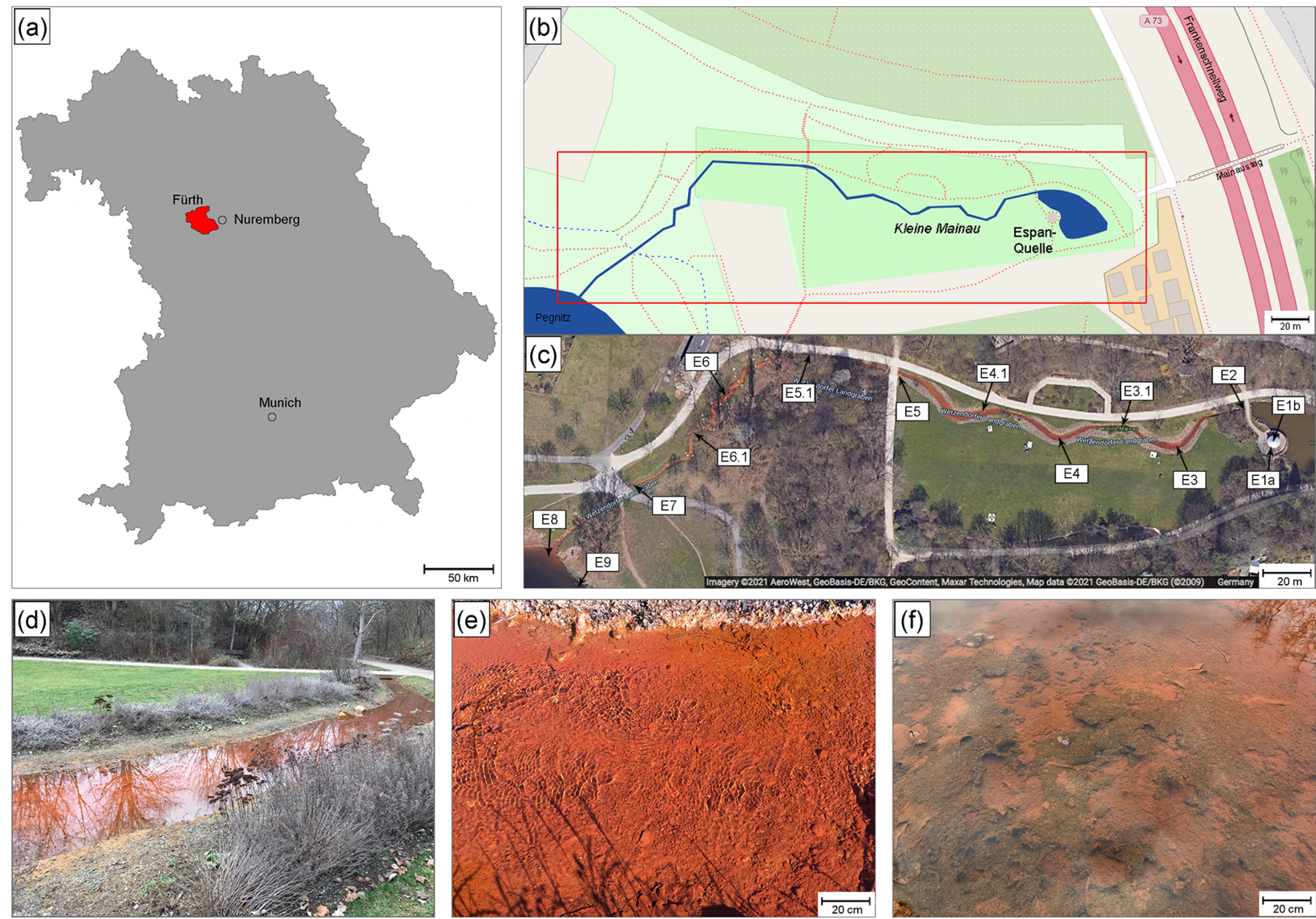

Figure 1. Overview of the Espan Spring in Fürth, Germany. (a) and (b): location of the spring in Bavaria and the city of Fürth. (c) Satellite image of the spring by Google maps showing the distinct red colour. (d) to (f): detailed photos of the system. (d) Displays the stream between sampling points E4 and E5, (e) shows sampling point E3 (with the bank of the water line in the upper part of the picture) and (f) displays sampling point E4.1 with algae and cyanobacteria mats.

to $371 \mathrm{~m}$ separates the Upper Main Buntsandstein from the Lower Main Buntsandstein and the so-called Eck'sche Conglomerate at a depth of 433 to $440 \mathrm{~m}$, which separates the Lower Main Buntsandstein from the Lower Buntsandstein (Birzer, 1936).

At a depth of 370 to $439 \mathrm{~m}$, mineral water flows into the borehole from the Upper Main Buntsandstein and Lower Main Buntsandstein and from the Eck Conglomerate. This water, which is caught in the red sandstone and has a temperature of about $+22^{\circ} \mathrm{C}$, was called the lower mineral water horizon; in 1936 its yield was about $10 \mathrm{~L} \mathrm{~s}^{-1}$ at a water temperature of $+23^{\circ} \mathrm{C}$ (Kühnau 1938). The water of this lower spring horizon is under artesian pressure and exits the spring with a head of about $13 \mathrm{~m}$ above ground level (Birzer, 1936). Nowadays the Espan Spring has a constant yield of about $5 \mathrm{Ls}^{-1}$.

After the water exits the basin in a pavilion with a temperature of $\sim 20^{\circ} \mathrm{C}$, it discharges into a stream of about $300 \mathrm{~m}$ length that is known as the Wetzendorfer Landgraben (WL).
This small stream drains into the river Pegnitz without any further tributaries (Fig. 1b, c). The water can be classified as a $\mathrm{Na}-\mathrm{Ca}-\mathrm{Cl}-\mathrm{SO}_{4}$ mineral water with initially undersaturated DO values of $2.3 \mathrm{mg} \mathrm{L}^{-1}$ and $\mathrm{Fe}$ (II) contents of up to $6.6 \mathrm{mg} \mathrm{L}^{-1}$ (Table 1). Figure 1c shows an aerial image of the spring and stream system that shows a distinct red colouring of the stream bed. The most plausible explanation for this colouring is iron-oxide precipitates (Fig. 1d, e). The WL has a water depth between $8-10 \mathrm{~cm}$ with few fluctuations.

\subsection{Sampling procedures}

Two field campaigns were performed in February and May 2020, during which water was collected at 14 locations along the stream. Data from these campaigns are available in Table 1. The on-site parameters of $\mathrm{pH}( \pm 0.05$; instrument precision), temperature $\left( \pm 0.1^{\circ} \mathrm{C}\right)$, electrical conductivity, Eh and DO (all $\pm 2 \%$ ) were measured with a Hach HQ40D multi-parameter instrument. Alkalinity titrations were car- 
ried out with a Hach titrator with a bromocresol-green indicator. $\mathrm{Fe}(\mathrm{II})$ and $\mathrm{Fe}$ (III) contents were measured using an iron (II-III) cuvette test set by Hach in combination with a portable Hach spectrophotometer (model DR 2800).

Samples for ${ }^{18} \mathrm{O} /{ }^{16} \mathrm{O}$ ratios of DO were collected in $12 \mathrm{~mL}$ Exetainers (Labco Ltd., Lampeter, UK) that were prepared with $10 \mu \mathrm{L}$ of a saturated $\mathrm{HgCl}_{2}$ solution to prevent secondary biological activity after sampling (Wassenaar and Koehler, 1999; Parker et al., 2005, 2010). The Exetainers were filled with syringe-filtered water via $0.45 \mu \mathrm{m}$ pore size nylon filters until they were entirely full and free of air bubbles. They were then carefully closed with screw caps with a butyl septum in order to avoid atmospheric contamination. Test series showed that the amount of atmospheric contamination during this filling procedure is usually negligible (Mader et al., 2018).

Samples for water isotopes were collected in $15 \mathrm{~mL}$ Falcon tubes and treated in the same manner as the ones for DO isotope measurements, except for preservation with $\mathrm{HgCl}_{2}$. All samples were stored in a mobile refrigerator box at $4{ }^{\circ} \mathrm{C}$ directly after collection and carried to the laboratory where they were measured within $24 \mathrm{~h}$.

\subsection{Identification of possible mineral precipitates}

In order to determine possible mineral precipitate data for the $\mathrm{pH}$, pe (the negative decadic activity of available electrons), temperature and alkalinity $\left(\right.$ as $\left.\mathrm{CaCO}_{3}\right)$, as well as cations and anions, the specific sampling points were fed into the program PHREEQC (Version 3; Parkhurst and Appelo, 2013) for calculation of saturation indices. The database used for these calculations was WATEQ4.

\subsection{Laboratory methods}

\subsubsection{Identification of cyanobacteria}

Samples were collected in a preliminary field assessment at the anoxic piping where the spring flows into the creek (E2), in the middle of the creek at the first small pond after the water had contact with the atmosphere (E3) and about $5 \mathrm{~m}$ downstream of this pond from an algal mat with bubbles on the surface (E4). Samples for cyanobacterial isolation were collected in sterile $2 \mathrm{~mL}$ Sarstedt tubes and sealed. Samples for microscopic analysis were collected with a $75 \%$ ethanolsterilized spatula and placed in a sterile $6 \mathrm{~cm}$ petri dish (Sarstedt, Germany). Immediately after returning from sampling, samples were embedded in $1.5 \%$ agarose in de-ionized water to preserve the structure of the bio mats during further handling and shipping.

Microscopic analysis was performed on thin sections of the embedded mats using a confocal laser scanning microscopy (CLSM) type microscope (LSM 880, Carl Zeiss), using modified acquisition settings from Jung et al. (2019) to discriminate between cyanobacterial (chlorophyll $a(\mathrm{Chl} a$ ) and phycobiliproteins (PBPs)) and green algal (Chl $a$ ) fluorescence. Laser transmission images were also generated using the $543 \mathrm{~nm}$ laser.

A spatula tip of green-coloured mat was used to inoculate $5 \mathrm{~mL}$ of BG11 medium (Stanier et al., 1971) in a well of a six-well plate and incubated for 3 weeks at $24^{\circ} \mathrm{C}$ on a $16: 8$ day: night cycle with illumination at $15 \mu$ mol photons $\mathrm{m}^{-2} \mathrm{~s}^{-1}$ under an OSRAM L $30 \mathrm{~W} / 840$ LUMILUX Cool White bulb. Individual cyanobacterial species were picked from the mat cultures under a Nikon SMZ-U Zoom binocular microscope for further subculturing on $1 \%$ agar-solidified BG11 plates, as well as in liquid culture. Isolates were observed under an Olympus BX53 light microscope, and their morphologies were recorded using an Olympus DP26 camera. The number of cells per filament and cell dimensions were measured using ImageJ $1.47 \mathrm{v}$ software. DNA was extracted (Gehringer et al., 2010) from one axenic isolate of a microscopically identified Persinema species of cyanobacteria. The 16S rDNA gene and intergenic spacer sequence were amplified by the SSU-4-forw and ptLSU C-Drev primer pair (Marin et al., 2005) using the Taq PCR Master Mix (Qiagen, Germany). The PCR product was purified (NucleoSpin PCR clean-up kit, Macherey-Nagel, Germany) and sequenced (Wilmotte et al., 1993). Sequences were merged (HVDR Fragment Merger tool; Bell and Kramvis, 2013), and the final 16S-ITS sequence was submitted to the National Center for Biotechnology Information (NCBI), National Institutes of Health, USA.

\subsubsection{Isotope measurements}

Stable isotope ratios of DO (expressed as $\delta^{18} \mathrm{O}_{\mathrm{DO}}$ ) were measured on a Delta V Advantage isotope ratio mass spectrometer (IRMS; Thermo Fisher Scientific, Bremen, Germany) coupled to an automated equilibration unit (GasBench II). Measurements were carried out in continuous-flow mode with a modified method by Barth et al. (2004). Here the isolation of DO into a headspace relies on a helium extraction technique by Kampbell et al. (1989) and Wassenaar and Koehler (1999). Different portions of laboratory air were injected into helium-flushed Exetainers and used to correct for linearity and instrumental drift during each run. Water isotopes were measured with an isotope ratio infrared spectroscopy analyzer (L-1102i, Picarro Inc., Santa Clara, CA, USA) according to a method by van Geldern and Barth (2012). Here laboratory air is defined to represent atmospheric oxygen with a ubiquitous value of $+23.9 \%$ versus Vienna Standard Mean Ocean Water (VSMOW) (Barkan and Luz, 2005). Data were normalized to this value.

$$
\delta=\left(R_{\text {sample }} / R_{\text {SMOW }}-1\right) \quad(\text { Clark and Fritz, } 1997)
$$

To obtain ratio changes in per mil (\%o), the $\delta$ values were multiplied by a factor of 1000 . 
All samples were measured in triplicates, and isotope value standard deviations $(1 \sigma)$ were less than $0.1 \%$ and $0.2 \%$ for $\delta^{18} \mathrm{O}_{\mathrm{H}_{2} \mathrm{O}}$ and $\delta^{18} \mathrm{O}_{\mathrm{DO}}$, respectively.

\section{Results and discussion}

\subsection{On-site parameters}

The on-site parameters as displayed in Table 1 show a range of $\mathrm{pH}$ values between 6.1 and 8.6 in the cold season and between 6.3 and 8.0 in the warm season. The observed changes in the $\mathrm{pH}$ over the course of the spring are mostly due to the constant degassing of $\mathrm{CO}_{2}$ from the spring. Oxygen values range from 2.3 to $11.0 \mathrm{mg} \mathrm{L}^{-1}$ in the cold season and from 3.6 to $8.8 \mathrm{mg} \mathrm{L}^{-1}$ in the warm season. Differences between the cold and warm season are due to the fact that cold water can dissolve more $\mathrm{O}_{2}$ than warm water. The general increase in the amount of DO over the course of the spring is due to a continuous dissolution of atmospheric $\mathrm{O}_{2}$ in the spring water and due to the impact of photosynthesis. Water temperatures ranged between 19.3 and $7.4^{\circ} \mathrm{C}$ in the cold season and between 21.3 and $25.7^{\circ} \mathrm{C}$ in the warm season. The conductivity remained stable over the course of the stream and only showed minor differences between the cold and warm season. The same applies to the alkalinity. The behaviour of the $\mathrm{Fe}$ (II) and $\mathrm{Fe}$ (III) is described in Sect. 3.5. Values of major ions $\left(\mathrm{Cl}^{-}, \mathrm{SO}_{4}^{2-}, \mathrm{NO}_{3}^{-}, \mathrm{Na}^{+}, \mathrm{K}^{+}, \mathrm{Ca}^{2+}\right.$ and $\left.\mathrm{Mg}^{2+}\right)$ remained constant over the course of the spring and show no differences between the cold and warm season.

\subsection{Precipitation calculations}

Precipitating mineral phases as determined with PHREEQC showed that the dominant phase at all measurement points was hematite $\left(\mathrm{Fe}_{2} \mathrm{O}_{3}\right)$ (Supplement Tables S1 and S2). Additionally, goethite $(\alpha-\mathrm{FeO}(\mathrm{OH}))$, ferrihydrite $\left(\mathrm{Fe}(\mathrm{OH})_{3}\right)$, siderite $\left(\mathrm{FeCO}_{3}\right)$ and $K$-jarosite $\left(\mathrm{KFe}_{3}^{3+}(\mathrm{OH})_{6}\left(\mathrm{SO}_{4}\right)_{2}\right)$ as well as $\mathrm{CaCO}_{3}$ and rhodochrosite $\left(\mathrm{MnCO}_{3}\right)$ showed elevated $\mathrm{SI}$ values and indicated precipitation.

\subsection{Bacterial contents}

CLSM showed that only the samples from Site E4.1 have photosynthetic organisms in significant quantities during the cold period. The photosynthetic community in this biofilm was dominated by cyanobacteria, with very few eukaryotic algae (Fig. 2). Lyngbya was observed along the sides of the fast-flowing stream on the smooth hard canal section at E2; however, the loosely built Lyngbya sp. mats were only observed in the wider, shallower sections from sampling sites E3 to E5 and predominating between sites E3.1 and E4.1. The Lyngbya sp. filaments were not encrusted by oxidized iron as proven by light microscopy. As these are simple cyanobacterial mats on top of loose iron oxides, with no additional microbial layers beneath them, the bubbles are pre-

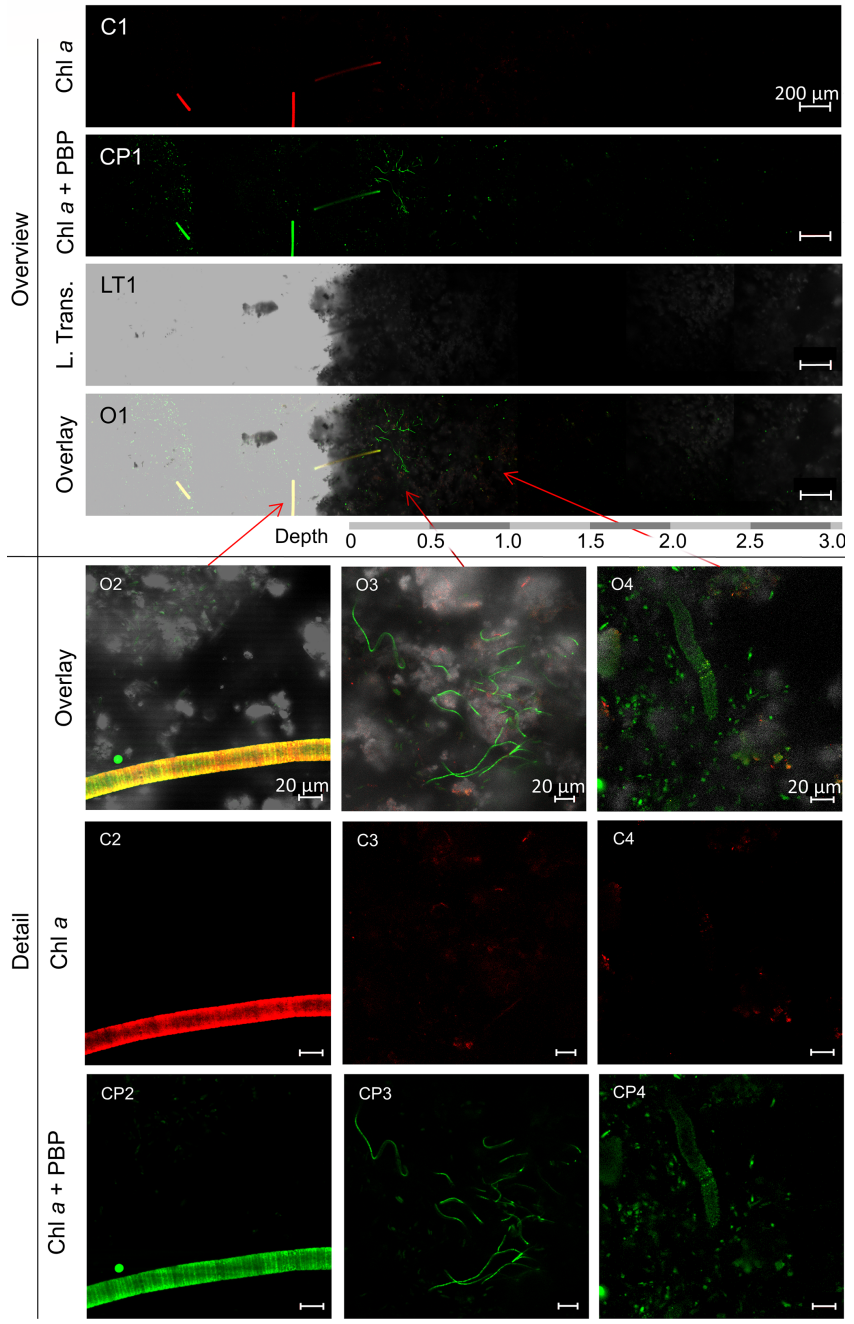

Figure 2. CLSM images of mat sample E4.1. Overview: images of the cross-section of the top $3 \mathrm{~mm}$ of the biofilm with the Chl $a$ (C1) and Chl $a$ plus PBP (CP1) fluorescence profile, complemented by a laser transmission picture (LT1) and the superimposed image (O1). Detail: superimposed images $(\mathrm{O} 2, \mathrm{O} 3, \mathrm{O} 4)$ of $\mathrm{Chl} a(\mathrm{C} 2, \mathrm{C} 3$, $\mathrm{C} 4)$ and Chl $a$ plus PBP (CP2, CP3, CP4) fluorescence and laser transmission (not shown) of distinct organisms found in the bio mat. O2: eukaryotic algae. O3: possible Klisinema- or Persinema-like sp. and a unicellular cyanobacterium. O4: Lyngbya-like sp. and a unicellular cyanobacterium.

sumably oxygen generated during photosynthesis (Supplement Fig. S1)

Most of the cyanobacteria and all eukaryotic algae were located in the topmost $1.2 \mathrm{~mm}$ of the biofilms (Fig. 2, O1). Close-up images show eukaryotic algae (Fig. 2, O2); thin filamentous cyanobacteria, possibly Persinema sp. or Klisinema sp. (Fig. 2, O3); and Lyngbya sp. (Fig. 2, O4). All pictures of the top layers of this sample site show an abundance of unidentified unicellular cyanobacteria, while images from the other sample sites show very few photosynthetic organisms at all (Supplement Fig. S2). 
Table 1. Field parameters, $\delta^{18} \mathrm{O}_{\mathrm{DO}}$ values, iron and uranium from sampling campaigns in February (cold season) and May (warm season) 2020 at the Espan Spring. Note that water isotopes are not listed here. They consistently ranged around a value of $-9.7 \%$.

\begin{tabular}{|c|c|c|c|c|c|c|c|c|c|c|c|}
\hline $\begin{array}{l}\text { Sampling } \\
\text { point }\end{array}$ & $\begin{array}{l}\text { Distance from } \\
\text { spring [m] }\end{array}$ & $\mathrm{pH}$ & $\begin{array}{r}\mathrm{O}_{2} \\
\text { [mg L-1] }\end{array}$ & $\begin{array}{r}\mathrm{O}_{2} \\
{[\%]}\end{array}$ & $\begin{array}{r}8^{18} \mathrm{O}_{\mathrm{Do}} \\
{[\% \mathrm{\%}]}\end{array}$ & $\begin{array}{r}\text { Temperature } \\
{\left[{ }^{\circ} \mathrm{C}\right]}\end{array}$ & $\begin{array}{r}\text { Conductivity } \\
{\left[\mathrm{mS} \mathrm{cm}^{-1}\right]}\end{array}$ & $\begin{array}{r}\text { Alkalinity as } \\
\mathrm{CaCO}_{3}\left[\mathrm{mg} \mathrm{L}^{-1}\right]\end{array}$ & $\begin{array}{r}\mathrm{Fe}^{2+} \\
{\left[\mathrm{mg} \mathrm{L}^{-1}\right]}\end{array}$ & $\begin{array}{r}\mathrm{Fe}^{3+} \\
{\left[\mathrm{mg} \mathrm{L}^{-1}\right]}\end{array}$ & {$\left[\begin{array}{l}\mathrm{U}^{\mathrm{t+}} \\
\left.\mathrm{L}^{-1}\right]\end{array}\right.$} \\
\hline \multicolumn{12}{|l|}{$\begin{array}{l}\text { Cold } \\
\text { season }\end{array}$} \\
\hline E1a & 0 & 6.1 & 2.3 & 25.3 & 23.7 & 19.5 & 16.8 & 820 & 6.6 & 0.4 & 170 \\
\hline E1b & 0 & 6.5 & 3.4 & 36.4 & 24.1 & 19.3 & 16.4 & 828 & 6.6 & 0.4 & 170 \\
\hline E2 & 15 & 6.5 & 4.5 & 48.6 & 24.5 & 19.3 & 16.5 & 796 & 5.6 & 0.4 & 170 \\
\hline$\overline{E 3}$ & 45 & 6.7 & 5.8 & 61.1 & 24.9 & 17.5 & 16.8 & 790 & 5.7 & 0.4 & 170 \\
\hline E3.1 & 65 & 6.5 & 7.4 & 76.9 & 25.4 & 17.3 & 16.6 & 810 & 4.5 & 0.5 & 170 \\
\hline $\mathrm{E} 4$ & 85 & 7.1 & 8.0 & 81.7 & 25.7 & 16.2 & 16.9 & 804 & 3.9 & 0.6 & 170 \\
\hline E4.1 & 115 & 7.5 & 8.7 & 88.1 & 25.3 & 16.1 & 17.0 & 808 & 3.4 & 0.6 & 170 \\
\hline E5 & 145 & 7.9 & 8.9 & 88.9 & 24.9 & 15.2 & 16.8 & 804 & 0.9 & 0.8 & 170 \\
\hline E5.1 & 175 & 7.6 & 9.1 & 90.4 & 24.7 & 15.3 & 16.8 & 816 & 0.4 & 0.5 & 170 \\
\hline E6 & 205 & 7.9 & 9.5 & 92.7 & 24.8 & 14.1 & 16.9 & 760 & 0.2 & 0.1 & 170 \\
\hline E6.1 & 235 & 7.9 & 9.7 & 92.9 & 24.7 & 13.3 & 16.5 & 770 & 0.0 & 0.1 & 170 \\
\hline E7 & 265 & 8.0 & 10.1 & 94.1 & 24.5 & 12.3 & 16.6 & 760 & 0.0 & 0.1 & 170 \\
\hline E8 & 295 & 8.0 & 10.5 & 94.6 & 24.6 & 10.8 & 1.1 & 195 & 0.0 & 0.1 & 5.0 \\
\hline E9 & 300 & 8.6 & 11.0 & 91.8 & 24.8 & 7.4 & 0.5 & 160 & 0.0 & 0.1 & 0.4 \\
\hline \multicolumn{12}{|l|}{$\begin{array}{l}\text { Warm } \\
\text { season }\end{array}$} \\
\hline E1a & 0 & 6.3 & 3.6 & 42.2 & 23.4 & 21.3 & 16.3 & 874 & 6.9 & 0.0 & 190 \\
\hline $\mathrm{E} 1 \mathrm{~b}$ & 0 & 6.4 & 3.9 & 42.2 & 23.5 & 21.2 & 16.4 & 850 & 6.7 & 0.1 & 190 \\
\hline E2 & 15 & 6.5 & 5.9 & 67.3 & 24.7 & 20.6 & 16.4 & 846 & 5.6 & 0.0 & 160 \\
\hline E3 & 45 & 6.6 & 6.6 & 75.3 & 24.5 & 21.6 & 16.4 & 814 & 4.0 & 0.0 & 160 \\
\hline E3.1 & 65 & 6.9 & 7.6 & 90.6 & 23.0 & 22.5 & 16.4 & 808 & 2.9 & 0.1 & 160 \\
\hline E4 & 85 & 7.2 & 8.2 & 97.9 & 23.0 & 22.7 & 16.4 & 826 & 1.5 & 0.1 & 160 \\
\hline E4.1 & 115 & 7.3 & 8.0 & 96.1 & 21.9 & 23.0 & 16.4 & 812 & 0.7 & 0.2 & 160 \\
\hline E5 & 145 & 7.4 & 8.1 & 97.9 & 21.8 & 24.0 & 16.4 & 786 & 0.1 & 0.1 & 160 \\
\hline E5.1 & 175 & 7.5 & 8.0 & 99.3 & 22.4 & 25.6 & 16.4 & 804 & 0.0 & 0.0 & 160 \\
\hline E6 & 205 & 7.5 & 8.1 & 100.1 & 23.2 & 25.7 & 16.4 & 796 & 0.0 & 0.0 & 160 \\
\hline E6.1 & 235 & 7.5 & 7.9 & 98.8 & 23.5 & 25.5 & 16.4 & 748 & 0.0 & 0.0 & 150 \\
\hline E7 & 265 & 7.5 & 8.1 & 99.5 & 24.0 & 24.9 & 16.4 & 742 & 0.0 & 0.0 & 150 \\
\hline E8 & 295 & 7.5 & 8.3 & 98.9 & 24.3 & 22.8 & 16.4 & 708 & 0.0 & 0.0 & 180 \\
\hline E9 & 300 & 8.0 & 8.8 & 92.1 & 23.7 & 16.8 & 0.8 & 238 & 0.0 & 0.0 & 1.0 \\
\hline
\end{tabular}

In order to determine the identity of the predominant cyanobacterial species isolated from the E4.1 enrichment cultures, a determination key was used to compare particular features of an isolate to those already in the literature for specific cyanobacterial species (Komárek und Anagnostidis, 2005). Note that enrichment cultures for samples E2 and E3 did not yield enough material for cyanobacterial determination after 5 weeks in culture.

The red-brown filamentous strain (Fig. 3c, d) exhibits single filaments, without false branching, that are 30.9 to $38.2 \mu \mathrm{m}$ wide (Table 2), with a firm 9.5 to $14 \mu \mathrm{m}$ thick sheath. The trichomes and single cells are 21.5 to $24.2 \mu \mathrm{m}$ wide and 1.5 to $4.1 \mu \mathrm{m}$ long (Table 2), red-brown in colour, and constricted at the cross walls. Based on these characteristics, the species was attributed to the cyanobacterial genus Lyngbya.

The blue-green filamentous strain (Fig. 3b) produces single filaments, without false branching, that are 3.9 to $7.6 \mu \mathrm{m}$ wide (Table 2) with a firm 2.7 to $3.1 \mu \mathrm{m}$ thick sheath. The trichomes and single cells are 1.2 to $4.5 \mu \mathrm{m}$ wide and 0.3 to $0.4 \mu \mathrm{m}$ long (Table 2) and blue-green in colour without constriction at the cross walls. The terminal cells in mature filaments are conical, elongated and bent to one side, corresponding to those of the Klisinema genus recently described by Heidari et al. (2018). The thin, naked, pale green filaments (Fig. 3a, e) resembled those of Persinema komarekii (Heidari
Table 2. Filament and cell dimensions of the proposed cyanobacterial species.

\begin{tabular}{lrrrr}
\hline & $\begin{array}{r}\text { Filament } \\
\text { length }\end{array}$ & $\begin{array}{r}\text { Filament } \\
\text { width } \\
(\mu \mathrm{m})\end{array}$ & $\begin{array}{r}\text { Cell } \\
\text { width } \\
(\mu \mathrm{m})\end{array}$ & $\begin{array}{r}\text { Cell } \\
\text { length } \\
(\mu \mathrm{m})\end{array}$ \\
\hline Lyngbya sp. & Indeterminate & $30.9-38.2$ & $21.5-24.2$ & $1.5-4.1$ \\
Klisinema sp. & Indeterminate & $3.9-7.6$ & $12-4.5$ & $0.3-0.4$ \\
Persinema. $\mathrm{sp}$ & Indeterminate & & $0.5-1.8$ & $2.7-4.7$ \\
\hline
\end{tabular}

et al., 2018) with apical cells flattened at the end. In contrast to the observations of Heidari et al. (2018), we observed terminal aerotopes. This species was purified in culture, and the 16S-ITS (NCBI accession number MT708471) sequence confirmed its identity as Persinema komarekii (MF348313).

\subsection{Dissolved oxygen (DO)}

The DO concentration in the Espan System was lowest at the faucet in the pavilion (sampling point E1a) with a saturation of $25.3 \%\left(2.3 \mathrm{mg} \mathrm{L}^{-1}\right)$ (Fig. 4a). Over the following $100 \mathrm{~m}$ DO saturation increased to $88.1 \%\left(8.7 \mathrm{mg} \mathrm{L}^{-1}\right)$ in sampling point E4.1. Afterwards the saturation continually increased to $94.6 \%\left(11.0 \mathrm{mg} \mathrm{L}^{-1}\right)$ in point E8. From an initial depth of $435 \mathrm{~m}$ with the abundance of reduced species 


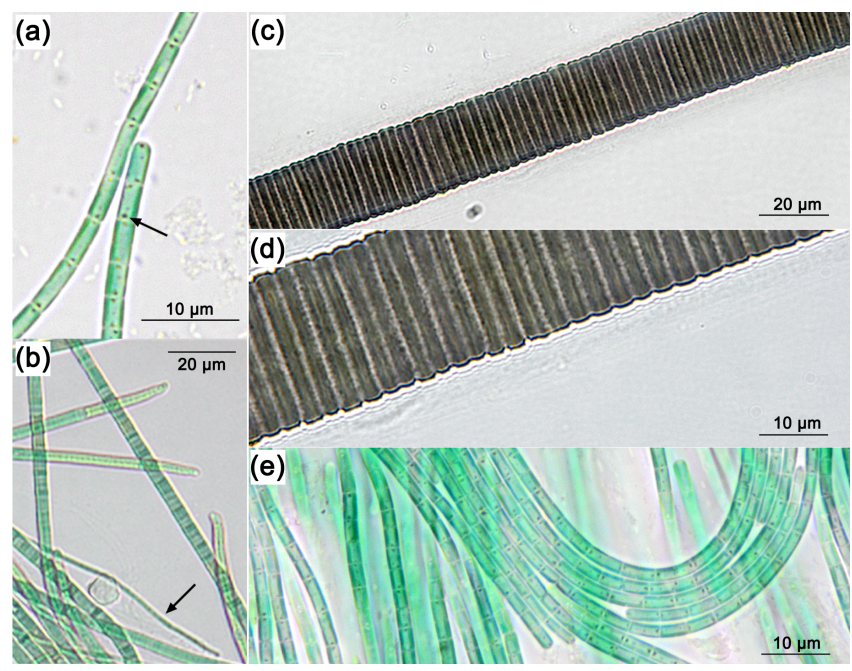

Figure 3. Light micrographs of the predominant isolates from sample E4.1: (a) single filament of Persinema sp., arrow indicates aerotopes. (b) Biofilm of Klisinema sp. interspersed with Persinema sp. (arrow). (c) Lyngbya sp. filament. (d) Lyngbya sp. sheath detail. (e) Biofilm of Persinema sp.

such as $\mathrm{Fe}(\mathrm{II})$ and $\mathrm{Mn}(\mathrm{II})$, the low DO content in sampling point E1a was expected, and further along the course, more atmospheric oxygen was able to dissolve. In addition, gas bubbles were observed in association with the Lyngbya mats. They were most prominent at sample site $\mathrm{E} 4.1$ and indicate a significant contribution of $\mathrm{O}_{2}$ from daytime photosynthesis. However, saturation with DO was not reached during either of the sampling campaigns.

\section{$3.5 \quad \mathrm{Fe}(\mathrm{II})$ and $\mathrm{Fe}(\mathrm{III})$}

The Fe(II) content was highest at the faucet with $6.6 \mathrm{mg} \mathrm{L}^{-1}$, while its lowest content was below instrument precision at sampling point E9 at $300 \mathrm{~m}$ from the source (Fig. 4b). $\mathrm{Fe}$ (II) concentrations decreased constantly over the stream course and were accompanied by increases in DO saturation (Fig. 4a). The decrease in Fe(II) could have been caused by three major processes:

1. oxidation of $\mathrm{Fe}(\mathrm{II})$ to form ferric iron minerals such as ferrihydrite, hematite and goethite;

2. precipitation of $\mathrm{Fe}(\mathrm{II})$ minerals such as the iron carbonate siderite $\left(\mathrm{FeCO}_{3}\right)$ and/or an amorphous ferrous silicate phase; or

3. adsorption of $\mathrm{Fe}(\mathrm{II})$ on already-formed iron minerals.

All three possibilities seem plausible when taking into consideration the saturation indices of ferric iron mineral goethite, ferrihydrite and hematite - precipitate at all sampling points in the system (Köhler et al., 2020). These calculations furthermore show that siderite can precipitate in almost all sampling points, while iron-silicate minerals are unlikely to precipitate. Therefore, adsorption of $\mathrm{Fe}$ (II) onto minerals is also a possible mechanism in the Espan System. Such adsorption of Fe(II) onto (oxyhydr)oxides was shown to typically occur under neutral conditions and should increase with rising pH (Zhang et al.,1992; Liger et al., 1999; Appelo et al., 2002; Sylvester et al., 2005). Moreover, large amounts of sulfate and chloride with average values of 2.2 and $4.5 \mathrm{~g} \mathrm{~L}^{-1}$ may have been responsible for maintaining observed high dissolved $\mathrm{Fe}$ (II) contents of the spring system at a circum-neutral $\mathrm{pH}$ despite rising DO concentrations. Such elevated $\mathrm{Cl}^{-}$and $\mathrm{SO}_{4}^{2-}$ contents can delay abiotic $\mathrm{Fe}$ (II) oxidation (Millero, 1985).

Dissolved Fe(III) was highest $\left(0.8 \mathrm{mg} \mathrm{L}^{-1}\right)$ at sampling point E5 after $145 \mathrm{~m}$ and lowest $\left(0.05 \mathrm{mg} \mathrm{L}^{-1}\right)$ at sampling point E7 after $265 \mathrm{~m}$ in flow distance from the spring. The values initially increased from $0.4 \mathrm{mg} \mathrm{L}^{-1}$ in E1a to a maximum of $0.8 \mathrm{mg} \mathrm{L}^{-1}$ in point $\mathrm{E} 5\left( \pm 0.03 \mathrm{mg} \mathrm{L}^{-1}\right)$ and then decreased to their lowest value in sampling point E7. The solubility of iron oxides in natural systems at a circum-neutral $\mathrm{pH}$ and under aerobic conditions is generally very low (Cornell and Schwertmann, 2003) with values of the solubility product $\left(K_{\mathrm{sp}}\right)$ between $10^{-37}$ and $10^{-44}$ (Schwertmann, 1991). However, $\mathrm{Fe}(\mathrm{III})$ could still be detected in the water, thus showing that its dissolution was possible. The dissolution of iron oxides can occur through several pathways including protonation, reduction and complexation that create $\mathrm{Fe}(\mathrm{III})$ cations and $\mathrm{Fe}$ (II) cations as well as $\mathrm{Fe}(\mathrm{II})$ and $\mathrm{Fe}(\mathrm{III})$ complexes (Schwertmann, 1991; Cornell and Schwertmann, 2003). Both the protonation and the reduction would lead to the formation of dissolved $\mathrm{Fe}(\mathrm{II})$. A steep increase in dissolved Fe(III) at $145 \mathrm{~m}$ downstream of the spring (from 0.5 to $0.8 \mathrm{mg} \mathrm{L}^{-1}$ ) also indicated acceleration of this process. One reason for this increase could be available organic matter. However, further analyses are needed to verify this interpretation.

\section{$3.6 \quad \delta^{18} \mathrm{O}_{\mathrm{DO}}$}

Figure $5 \mathrm{a}$ and $\mathrm{b}$ show $\delta^{18} \mathrm{O}_{\mathrm{DO}}$ values over the course of the spring for the cold and warm seasons, respectively. The curves are divided into two zones for the cold season and three zones for the warm season.

\section{Zone 1}

In the cold season, zone 1 extended from sampling point E1a to point E4. In this first $85 \mathrm{~m}$, the $\delta^{18} \mathrm{O}_{\mathrm{DO}}$ increased from a value of $+23.7 \%$ at the faucet (E1a) to $+25.7 \%$ at E4 In the warm season, zone 1 extended from E1a to E2 with only a $15 \mathrm{~m}$ distance from the spring. In this zone the values increased from $+23.4 \%$ at the faucet to a maximum value of $+24.7 \%$ at E2. In both seasons, $\delta^{18} \mathrm{O}_{\mathrm{DO}}$ values at E1a were below the value expected for atmospheric equilibration $\left(+24.6 \%\right.$ o). At first sight, such ${ }^{16} \mathrm{O}$-enriched $\delta^{18} \mathrm{O}_{\mathrm{DO}}$ values 
(a)

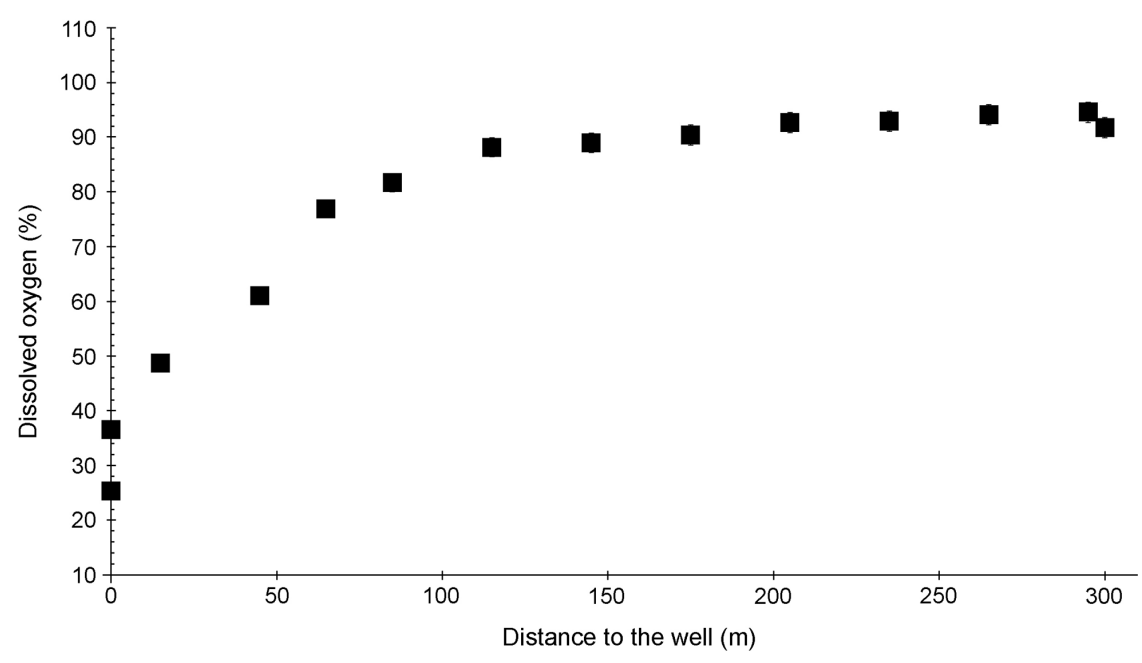

(b)

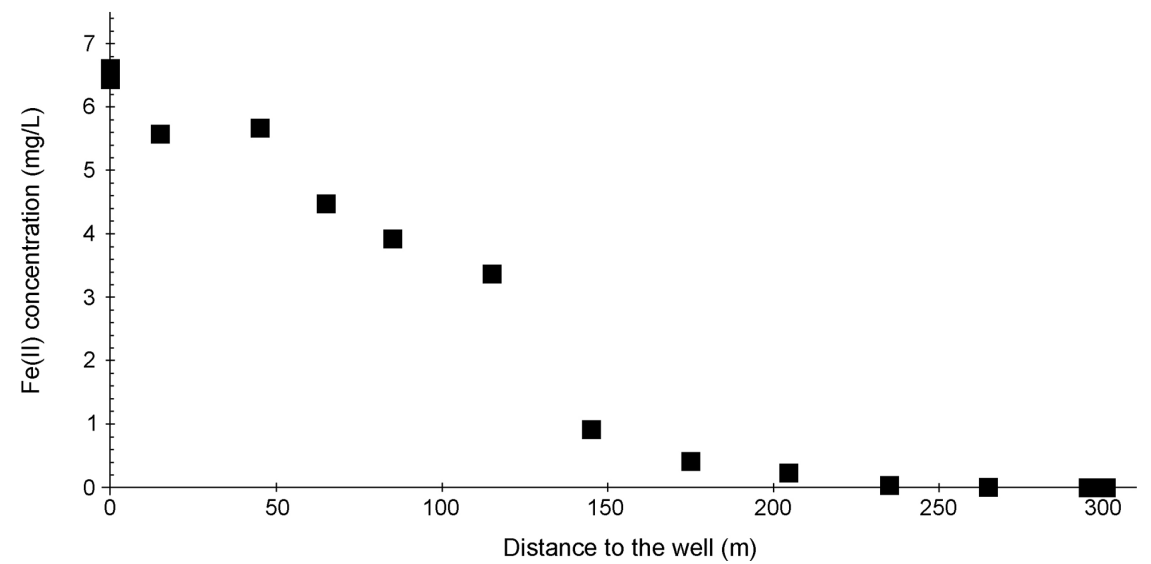

Figure 4. (a) Dissolved oxygen (\%) and (b) Fe(II) concentrations over the course of the Espan System in an example graph for the cold season in February. The error for DO was $2 \%$, and for $\mathrm{Fe}(\mathrm{II})$ it was $0.06 \mathrm{mg} \mathrm{L}^{-1}$. Errors are within the symbol size.

would suggest photosynthetic input of DO. However, the water originated from greater depths without any exposure to light, and thus any photosynthetic influence can be ruled out.

The occurrence of $\delta^{18} \mathrm{O}_{\mathrm{DO}}$ values below $+24.6 \%$ in groundwater has been described in the literature (Wassenaar and Hendry, 2007; Smith et al., 2011; Parker et al., 2014; Mader et al., 2018), and several explanations for this phenomenon have been suggested (Wassenaar and Hendry, 2007; Smith et al., 2011; Parker et al., 2014; Mader et al., 2018). These include

1. possible transfer of photosynthetic or diffusive oxygen into the shallow aquifer (Smith et al., 2011; Parker et al., 2014; Mader et al., 2018),
2. radial oxygen loss of plant roots (Teal and Kanwisher, 1966; Michaud and Richardson, 1989; Caetano and Vale, 2002; Armstrong and Armstrong, 2005b),

3. radiolysis of water (Wassenaar and Hendry, 2007), and

4. kinetic gas transfer (Benson and Krause, 1980; Knox et al., 1992; Mader et al., 2017)

Explanations (1) and (2) are very unlikely in the Espan Spring because the water originates from a depth of $435 \mathrm{~m}$ below ground through pipes that presumably prevent any exchange with surface water or possible impacts of plant roots. It should however be noted that water from the Espan Spring contains up to $170 \mu \mathrm{g} \mathrm{L}^{-1}$ of uranium from easily soluble uranium compounds that are commonly encountered in the Buntsandstein Formation (Büttner et al., 2006; Meurer and 
(a)

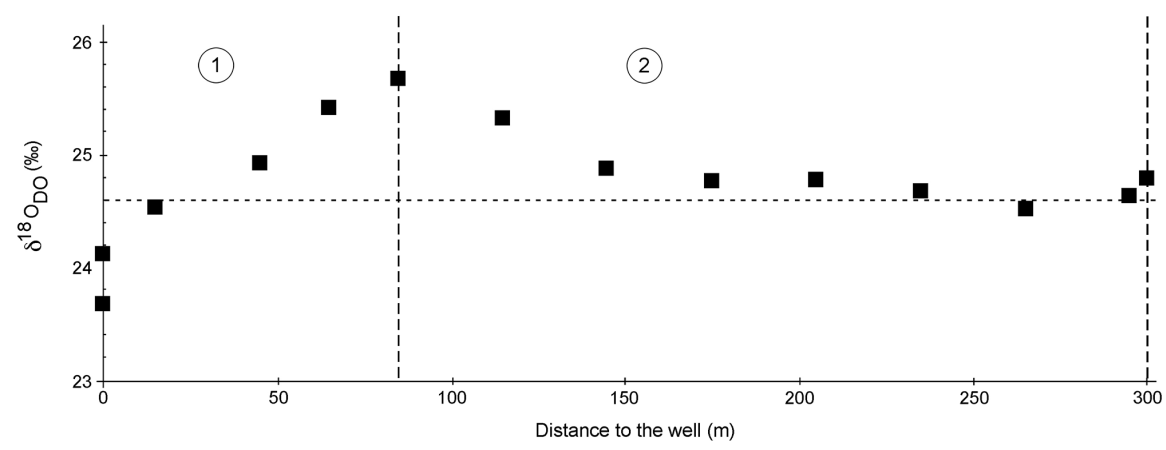

(b)

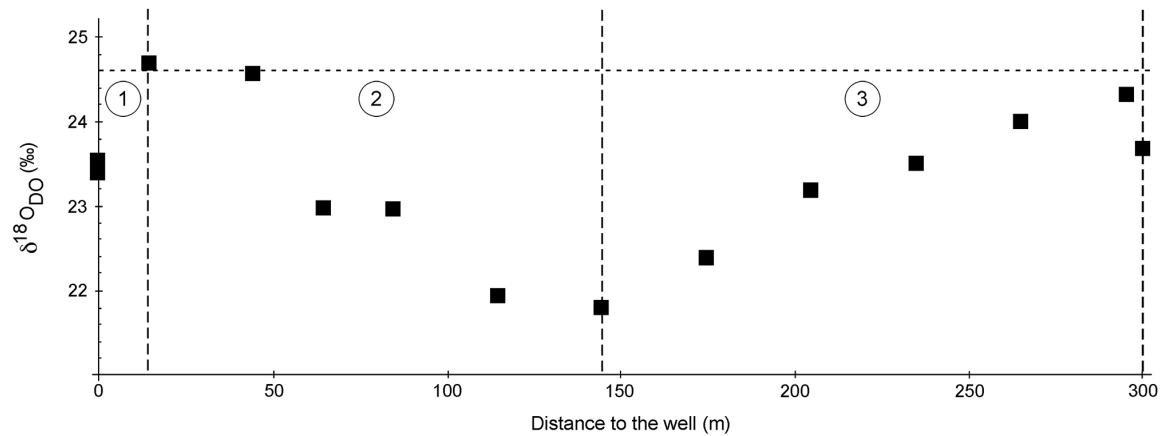

Figure 5. $\delta^{18} \mathrm{O}_{\mathrm{DO}}$ in the cold season (a) and the warm season (b) over the course of the Espan Spring and stream system with the atmospheric equilibrium value of $+24.6 \%$ marked by the horizontal dashed lines. Dashed vertical lines show borders of the different zones of the fields labelled with 1, 2 and 3 . The symbol size is larger than the error bars.

Banning, 2019). The geogenic radiation in the area is rather high because of the high uranium content in the Variscian bedrocks of the area (Schwab, 1987; Büttner et al., 2006). Because of this, radiolysis could be a possible explanation for the unexpectedly low $\delta^{18} \mathrm{O}_{\mathrm{DO}}$ values. Kinetic gas transfer of atmospheric oxygen during transport in the pipes or at the faucet might be another explanation, since the sample in E1a is strongly DO undersaturated. During non-equilibrium gas exchange the kinetically faster ${ }^{16} \mathrm{O}$ would cause $\delta^{18} \mathrm{O}_{\mathrm{DO}}$ below $+24.6 \%$ until equilibrium is established (Benson and Krause, 1980; Knox et al., 1992; Mader et al., 2017).

Increases in $\delta^{18} \mathrm{O}_{\mathrm{DO}}$ values in zone 1 were accompanied by increases in DO (Fig. 6a). In the cold season, a strong positive correlation was evident between points E1a and E4. However, in the warm season, the same correlation could only be observed between points E1a and E2 (Fig. 6b). Equilibration with the atmosphere would be a reasonable explanation for this trend until atmospheric equilibration is reached between points E2 and E3. However, the $\delta^{18} \mathrm{O}_{\mathrm{DO}}$ values, at least in the cold season, increased above this threshold to a value of $+25.7 \%$. This shows that another process in addition to atmospheric equilibration must have influenced the $\delta^{18} \mathrm{O}_{\mathrm{DO}}$ values in zone 1 . In the warm season, this was less evident, and the isotope atmospheric equilibrium value was only marginally exceeded and remained within the range of the analytical uncertainties.

Even though these processes consume DO, both respiration and iron oxidation could be responsible for this trend when assuming that they influence the $\delta^{18} \mathrm{O}_{\mathrm{DO}}$ values, while DO concentrations are constantly replenished by the atmosphere. A direct negative correlation between $\mathrm{Fe}(\mathrm{II})$ concentrations and $\delta^{18} \mathrm{O}_{\mathrm{DO}}$ values between point $\mathrm{E} 1 \mathrm{a}$ and $\mathrm{E} 4$ was evident for cold-season samples and in points E1a and E2 for warm-season samples as shown in Fig. $6 \mathrm{c}$ and d. This correlation between $\mathrm{Fe}(\mathrm{II})$ and $\delta^{18} \mathrm{O}_{\mathrm{DO}}$ in the Espan System corresponds with the experimental observations of Oba and Poulson (2009a), as well as those of Pati et al. (2016). These studies demonstrate that $\mathrm{Fe}$ oxidation leads to increases in $\delta^{18} \mathrm{O}_{\mathrm{DO}}$ values due to preferential consumption of ${ }^{16} \mathrm{O}$. The increase in $\delta^{18} \mathrm{O}_{\mathrm{DO}}$ due to iron oxidation in a natural system, which is constantly supplied with fresh oxygen, indicates that $\mathrm{Fe}(\mathrm{II})$ oxidation must be a dominant control on $\delta^{18} \mathrm{O}_{\mathrm{DO}}$ in the first $85 \mathrm{~m}$ of the stream in the cold season and in the first $15 \mathrm{~m}$ in the warm season. It also implies that the direct impact of oxygen addition is subordinate in terms of DO stable isotope changes. This is shown by iron oxidation being the dominant factor that controls $\delta^{18} \mathrm{O}_{\mathrm{DO}}$ values, even though oxygen is constantly supplied from the atmosphere. 
(a)

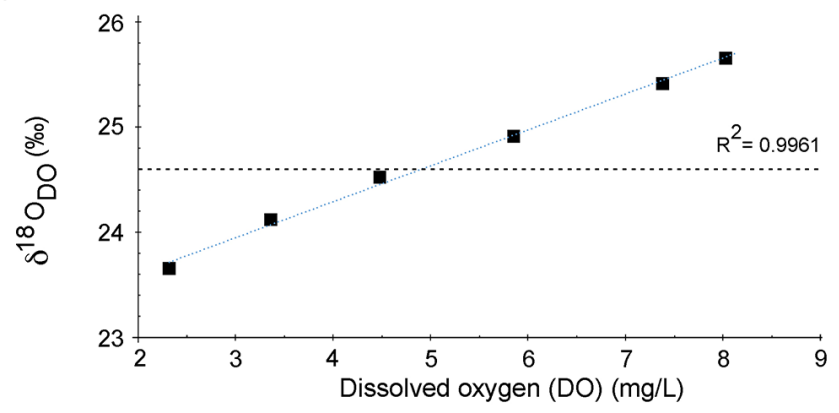

(c)

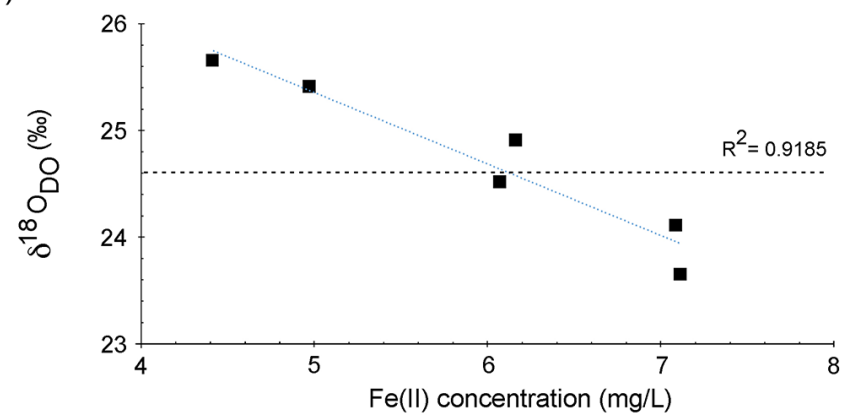

(b)

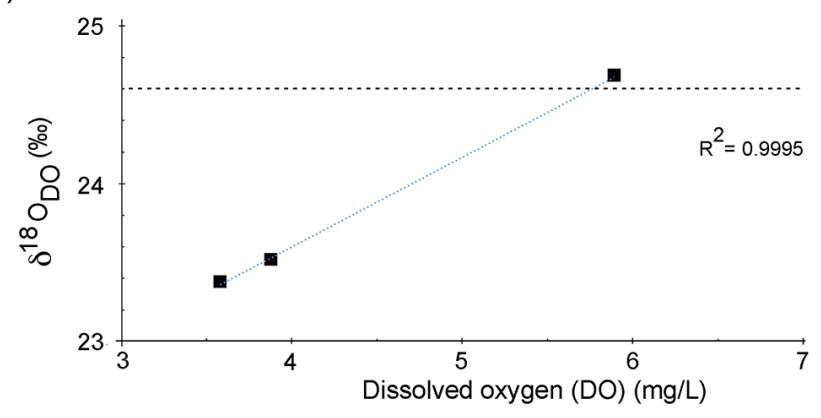

(d)

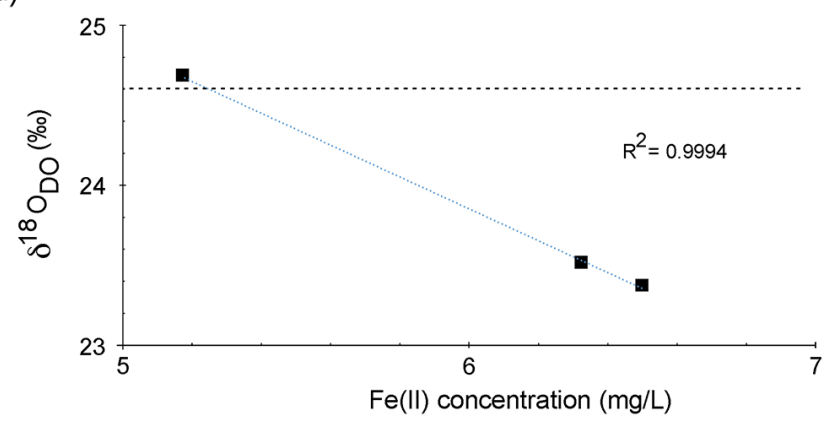

Figure 6. Correlation between $\delta^{18} \mathrm{O}_{\mathrm{DO}}$ and DO over the course of the spring for zone 1 in the cold season (a) and the warm season (b). Correlation between $\delta^{18} \mathrm{O}_{\mathrm{DO}}$ and $\mathrm{Fe}(\mathrm{II})$ contents over the course of the stream for zone 1 in the cold season (c) and the warm season (d).

\section{Zone 2}

In the cold season, zone 2 extended from sampling point $\mathrm{E} 4$ to point $\mathrm{E} 9$ with only minor variations in $\delta^{18} \mathrm{O}_{\mathrm{DO}}$. In this zone, the $\delta^{18} \mathrm{O}_{\mathrm{DO}}$ decreased from $+25.7 \%$ in sampling point $\mathrm{E} 4$ to values around atmospheric equilibrium with $+24.5 \%$ o in E7 and $+24.8 \%$ in the Pegnitz (Fig. 5a).

In the warm season, zone 2 extended from sampling point $\mathrm{E} 2$ to point $\mathrm{E} 5$ at a $145 \mathrm{~m}$ distance from the spring. In this zone the values decreased from $+24.7 \%$ o to a minimum value of $+21.8 \%$ in sampling point E5 (Fig. $5 \mathrm{~b}$ ). This decrease in $\delta^{18} \mathrm{O}_{\mathrm{DO}}$ values can be explained by (1) a decrease in the impact of iron oxidation on the $\delta^{18} \mathrm{O}_{\mathrm{DO}}$ values and (2) a rising impact of atmospheric or photosynthetic oxygen. Even though a decrease in Fe(II) values was still evident between E4 and E7 in the cold season, as well as between E2 and E5 in the warm season, it is possible that the decrease was not caused by $\mathrm{Fe}$ (II) oxidation and subsequent precipitation as iron oxides. Alternatively, the decrease could have been caused by adsorption of dissolved Fe(II) onto already-existing iron oxides such as goethite, ferrihydrite and hematite (Zhang, et al., 1992; Liger et al., 1999; Appelo et al., 2002; Sylvester et al., 2005). Because adsorbed Fe(II) is very resistant to oxidation (Park and Dempsey, 2005), the impact of iron oxidation on the $\delta^{18} \mathrm{O}_{\mathrm{DO}}$ values would have decreased.

No significant changes in the water chemistry were evident, and it can be assumed that after sampling point E2 (warm season) or E4 (cold season), a critical value was exceeded with enough $\mathrm{Fe}$ (II) having been adsorbed onto iron oxides. In this case, iron oxidation - while probably still taking place at small rates - is no longer an important factor dominating the $\delta^{18} \mathrm{O}_{\mathrm{DO}}$ values. Downstream of points E2 and $\mathrm{E} 4$, oxygen addition by the atmosphere or by photosynthesis would become more important.

Intensive growth of cyanobacterial and algal mats were observed between point E3.1 and E5 in the cold season and between E3 and E5 in the warm season (Fig. 1f). Because of this growth, it can be postulated that in addition to the atmospheric $\mathrm{O}_{2}$ input, the $\delta^{18} \mathrm{O}_{\mathrm{DO}}$ values were also influenced by photosynthetically produced oxygen. While this effect should be less pronounced in the cold and darker season, a stronger influence of photosynthetic oxygen on the $\delta^{18} \mathrm{O}_{\mathrm{DO}}$ values would be expected in the warm season with higher light intensity. Such growth of photosynthetic organisms in the Espan System is not surprising with iron being an important micronutrient (Andrews et al., 2003).

The fact that photosynthesizing organisms seem to preferentially grow and impact the $\delta^{18} \mathrm{O}_{\mathrm{DO}}$ values between sampling points E3 and E5 may be due to the availability of $\mathrm{Fe}(\mathrm{II})$. In addition, the growth could also be controlled by changes in the $\mathrm{pH}$ or other environmental influences, with the site being located in a public park with the associated perturbations. Cyanobacteria, especially aquatic strains, prefer a neutral to alkaline $\mathrm{pH}$ (Brock, 1973), and the shift to higher $\mathrm{pH}$ values in this zone could be one of the main factors 
that drive an increased supply of cyanobacterial $\mathrm{O}_{2}$. For instance, Lyngbya spp. are diazotrophic cyanobacteria, capable of fixing nitrogen during low availability of light, when local oxygen levels are low (Stal, 2012, p. 102). This oxygen released through oxygenic photosynthesis would immediately react with $\mathrm{Fe}(\mathrm{II})$ and lower the partial pressure of oxygen around the organisms in a slow-flowing stream. This could also favour biological nitrogen fixation and limit carbon loss by reducing photorespiration. Additionally, the reduced oxygen partial pressure induced by $\mathrm{Fe}(\mathrm{II})$ oxidation may minimize the oxygenase activity of ribulose 1,5-bisphosphate carboxylase/oxygenase (Rubisco), thereby favouring $\mathrm{CO}_{2}$ fixation (Stal, 2012, p. 113).

A screening of microbial ecology in several iron-rich circum-neutral springs and experiments with the cyanobacterium Synechococcus PCC 7002 (Swanner et al., 2015) revealed that many cyanobacteria show optimal growth between $0.4-3.1 \mathrm{mg} \mathrm{L}^{-1}$ of $\mathrm{Fe}(\mathrm{II})$ and that concentrations above $4.5 \mathrm{mg} \mathrm{L}^{-1}$ become growth-limiting. The iron concentrations between points E3.1 and E5 in the cold season and E3 and E5 in the warm season are thus approximately in the range of optimal cyanobacterial growth. In order to establish a clear correlation between the iron concentration and the decrease in $\delta^{18} \mathrm{O}_{\mathrm{DO}}$ values, experiments would need to be carried out with the organisms found in the Espan System. These have so far have not been assessed for their behaviour under variable iron concentrations.

\section{Zone 3}

In the warm season, zone 3 extended from sampling point $\mathrm{E} 5$ to point $\mathrm{E} 8$. In this zone the $\delta^{18} \mathrm{O}$ values rose again from $+21.8 \%$ o to $+24.3 \%$ o (Fig. 5 b). The renewed increase in values can be explained by the influence of iron oxidation, respiration and a decrease in photosynthetic activity. Because $\mathrm{Fe}$ contents only decreased marginally, it can be assumed that decreases in photosynthetic activities are responsible for increases in the $\delta^{18} \mathrm{O}$ values. This matches our observations that downstream of point E5, only a little or no photosynthetic growth took place. Oxygen that would dissolve in the water after point E5 would thus most likely stem from the atmosphere. This would also explain the approach to the equilibrium value of $+24.6 \%$ o. Reasons for the observed decrease in cyanobacteria are however not clear and may include changes in temperature and light intensity and shifts in nutrient availability.

The temperature did not change significantly in this part of the watercourse and is therefore unlikely to have caused a decrease in photosynthetic oxygen production. In contrast, reduced light exposure could have been responsible as downstream of point E5 trees shade the watercourse. A decrease in nutrient availability is difficult to determine because nitrate and phosphate were below the detection limit in the entire spring. Iron starvation could also be a possible reason for the decrease in activity because only $\sim 0.005 \mathrm{mg} \mathrm{L}^{-1}$ of $\mathrm{Fe}$ (II) was left in the system in the lowest course of the stream.

\section{Conclusions}

Our study is the first systematic analysis of $\delta^{18} \mathrm{O}_{\mathrm{DO}}$ values as a function of iron contents and oxygenic photosynthetic biofilms in a natural iron-rich stream. We were able to confirm from field samples that $\mathrm{Fe}$ oxidation leads to increases in $\delta^{18} \mathrm{O}_{\mathrm{DO}}$ values even though oxygen was constantly replenished by atmospheric input. As soon as photosynthetic oxygen is produced in the system, the effect of iron oxidation on the $\delta^{18} \mathrm{O}_{\mathrm{DO}}$ values becomes negligible and can no longer be detected. The fact that photosynthesis has a strong impact on the $\delta^{18} \mathrm{O}_{\mathrm{DO}}$ values in specific areas of the system may be controlled by high Fe contents. Similar iron-rich springs show optimal growth rates of cyanobacteria in the range of 0.4 $3.1 \mathrm{mg} \mathrm{L}^{-1}$ of $\mathrm{Fe}(\mathrm{II})$. The presented $\delta^{18} \mathrm{O}_{\mathrm{DO}}$ values showed that photosynthetic activity is also strongest in the Espan System within this range of concentrations.

To what extent the changing $\mathrm{Fe}$ concentrations (Fe(II)$\mathrm{Fe}(\mathrm{III}))$ influence the growth of cyanobacteria and algae occurring in the Espan System requires further investigation. This would ideally include isolating the organisms from the watercourse and studying them under varying experimental levels of $\mathrm{Fe}, \mathrm{pH}$ and temperature while monitoring the $\delta^{18} \mathrm{O}_{\mathrm{DO}}$ of the system. Further field studies with organic material from the stream bed in combination with stable carbon isotopes would be promising to narrow down processes for carbon and oxygen budgets in this environment.

Code availability. The code PHREEQC is available under https:// www.usgs.gov/software/phreeqc-version-3 (Parkhurst and Appelo, 2009).

Data availability. All data of this study are available in this text and in the Supplement.

Supplement. The supplement related to this article is available online at: https://doi.org/10.5194/bg-18-4535-2021-supplement.

Author contributions. IK, DP and JACB carried out the sample collection and water analysis for on-site and isotope data. REM carried out the calculation of the saturation index. MMG, AJH and AG performed the analysis and interpretation of cyanobacteria and algae data. IK prepared the manuscript with contributions from all coauthors.

Competing interests. The authors declare that they have no conflict of interest. 
Disclaimer. Publisher's note: Copernicus Publications remains neutral with regard to jurisdictional claims in published maps and institutional affiliations.

Acknowledgements. Funding for this project was made available by the German Research Foundation (DFG) through the Project IsoDO awarded to Johannes Barth and further DFG grants awarded to Michelle Gehringer. We also thank Christian Hanke, Marlene Dordoni and Marie Singer for help with sampling and analyses. Contributions by David Piatka were also carried out in the framework of the project AquaKlif in the bayklif network for investigation of regional climate change funded by the Bavarian State Ministry of Science and the Arts.

Financial support. This research has been supported by the German Research Foundation (DFG) (grant nos. BA2207/15-1, GE2558/3-1, GE2558/4-1).

Review statement. This paper was edited by Tina Treude and reviewed by two anonymous referees.

\section{References}

Andrews, S. C., Robinson, A. K., and Rodríguez-Quiñones, F.: Bacterial iron homeostasis, FEMS Microbiol. Rev., 27, 215-237, https://doi.org/10.1016/S0168-6445(03)00055-X, 2003.

Appelo, T., Van der Weiden, M. J., Tournassat, C., and Charlet, L.: Surface Complexation of Ferrous Iron and Carbonate on Ferrihydrite and the Mobilization of Arsenic, Environ. Sci. Technol., 36, 3096-3103, https://doi.org/10.1021/es010130n, 2002.

Armstrong, W. and Armstrong, J.: Stem photosynthesis not pressurised ventilation is responsible for light-enhanced oxygen supply to submerged roots of alder (Alnus glutinosa), Ann. Bot., 96, 591-612, https://doi.org/10.1093/aob/mci213, 2005.

Barkan, E. and Luz, B.: High precision measurements of ${ }^{17} \mathrm{O} /{ }^{16} \mathrm{O}$ and ${ }^{18} \mathrm{O} /{ }^{16} \mathrm{O}$ ratios in $\mathrm{H}_{2} \mathrm{O}$, Rapid Commun. Mass Sp., 19, 3737-3742, https://doi.org/10.1002/rcm.2250, 2005.

Barth, J. A. C., Tait, A., and Bolshaw, M.: Automated analyses of O-18/O-16 ratios in dissolved oxygen from 12$\mathrm{mL}$ water samples, Limnol. Oceanogr. Method., 2, 35-41, https://doi.org/10.4319/lom.2004.2.35, 2004

Bell, T. G. and Kramvis, A.: Fragment Merger: An Online Tool to Merge Overlapping Long Sequence Fragments, Viruses, 5, 824833, https://doi.org/10.3390/v5030824, 2013.

Benson, B. B. and Krause D.: The concentration and isotopic fractionation of gases dissolved in freshwater in equilibrium with the atmosphere. 1. Oxygen, Limnol. Oceanogr., 25, 662-671, https://doi.org/10.4319/1o.1980.25.4.0662, 1980.

Büttner, G., Stichler, W., and Scholz M.: Hydrogeochemische Untersuchungen in den Forschungsbohrungen Lindau 1 und Spitzeichen 1 (Fränkisches Bruchschollenland), Geol. Bavar., 109, 105-124, 2006.

Birzer, F.: Eine Tiefbohrung durch das mesozoische Deckgebirge in Fürth in Bayern, Stuttgart, Zbl. Min. etc., Abt. B, 425-433, 1936.
Brock T. D.: Lower pH limit for the existence of blue-green algae: evolutionary and ecological implications, Science, 179, 480-483, https://doi.org/10.1126/science.179.4072.480 1973.

Caetano, M. and Vale, C.: Retention of arsenic and phosphorus in iron-rich concretions of Tagus salt marshes, Mar. Chem., 79, 261-271, https://doi.org/10.1016/S0304-4203(02)00068-3, 2002.

Clark, I. D. and Fritz, P. (Eds.): Environmental Isotopes in Hydrogeology, CRC Press/Lewis, Boca Raton, USA, 1997.

Cornell, R. M. and Schwertmann, U. (Eds.): The Iron Oxides: Structure, Properties, Reactions, Occurrences and Uses, Wiley-VCH Verlag, Weinheim, Germany, 2003.

Eisenstadt, D., Barkan, E., Luz, B., and Kaplan, A.: Enrichment of oxygen heavy isotopes during photosynthesis in phytoplankton, Photosynth. Res., 103, 97-103, https://doi.org/10.1007/s11120009-9518-z, 2010.

Gammons, C. H., Henne, W., Poulson, S. R., Parker, S. R., Johnston, T. B., Dore, J. E., and Boyd, E. S.: Stable isotopes track biogeochemical processes under seasonal ice cover in a shallow, productive lake, Biogeochemistry, 120, 359-379, https://doi.org/10.1007/s10533-014-0005-z, 2014.

Gehringer, M. M., Pengelly, J. J. L., Cuddy, W. S., Fieker, C., Foster, P. I., and Neilan, B. A.: Host selection of symbiotic cyanobacteria in 21 species of the Australian cycad genus: Macrozamia (Zamiaceae), Mol. Plant. Microbe. Interact., 23, 811-822, https://doi.org/10.1094/MPMI-23-6-0811, 2010.

Guy, R. D., Fogel, M. L., and Berry J. A.: Photosynthetic fractionation of the stable isotopes of oxygen and carbon, Plant Physiol., 101, 37-47, https://doi.org/10.1104/pp.101.1.37, 1993.

Heidari, F., Zima, J., Riahi, H., and Hauer, T.: New simple trichal cyanobacterial taxa isolated from radioactive thermal springs, Fottea. Olomouc., 18, 137-149, https://doi.org/10.5507/fot.2017.024, 2018.

Jung, P., Briegel-Williams, L., Schermer, M., and Büdel, B.: Strong in combination: Polyphasic approach enhances arguments for cold-assigned cyanobacterial endemism, Microbiologyopen, 8, e00729, https://doi.org/10.1002/mbo3.729, 2019.

Kampbell, D. H., Wilson, J. T., and Vandegrift, S. A.: Dissolvedoxygen and methane in water by a Gc headspace equilibration technique, Int. J. Environ. Anal. Chem., 36, 249-257, https://doi.org/10.1080/03067318908026878, 1989.

Kappler, A., Bryce, C., Mansor, M., Lueder, U., Byrne, J. M., and Swanner, E. D.: An evolving view on biogeochemical cycling of iron, Nat. Rev. Microbiol., 19, 360-374, https://doi.org/10.1038/s41579-020-00502-7, 2021.

Kühnau, J.: Balneologisches Gutachten über die Heilwirkungen, welche von den im Stadtgebiet von Fürth erbohrten Mineralquellen zu erwarten sind, Unveröff. Gutachten, 14 S., 3 Tab., Wiesbaden, 1938.

Knox, M., Quay, P. D., and Wilbur, D.: Kinetic isotopic fractionation during air-water gas transfer of $\mathrm{O}_{2}, \mathrm{~N}_{2}$; $\mathrm{CH}_{4}$, and $\mathrm{H}_{2}$, J. Geophys. Res.-Ocean., 97, 20335-20343, https://doi.org/10.1029/92JC00949, 1992.

Köhler, I., Piatka, D., Barth, J. A. C., and Martinez, R. E.: Beware of effect on isotopes of dissolved oxygen during storage of natural iron-rich water samples: A technical note, Rapid Commun. Mass Sp., 35, e9024, https://doi.org/10.1002/rcm.9024, 2020.

Komárek, J. and Anagnostidis, K.: Cyanoprokaryota, 2. Oscillatoriales, in: Süsswasserflora von Mitteleuropa, edited by: Büdel, B., 
Krienitz, L., Gärtner, G., and Schagerl, M., Elsevier/Spektrum, Heidelberg, Germany, 760 pp., 2005.

Kritzberg, E. S. and Ekström, S. M.: Increasing iron concentrations in surface waters - a factor behind brownification?, Biogeosciences, 9, 1465-1478, https://doi.org/10.5194/bg-9-14652012, 2012.

Kritzberg, E. S., Maher, Hasselquist, E., Skerlep, M., Löfgren, S., Olsson, O., Stadmark, J., Valinia, S., Hansson, L. A., and Laudon, H.: Browning of freshwaters: Consequences to ecosystem services, underlying drivers, and potential mitigation measures, Ambio, 49, 375-390, https://doi.org/10.1007/s13280-01901227-5, 2020.

Kroopnick, P. M.: Respiration, photosynthesis, and oxygen isotope fractionation in oceanic surface waters, Limnol. Oceanogr., 20, 988-992, https://doi.org/10.4319/lo.1975.20.6.0988, 1975.

Liger, E., Charlet, L., and Van Cappellen, P.: Surface Catalysis of Uranium(VI) Reduction by Iron(II), Geochim. Cosmochim. Ac., 63, 2939-2955, https://doi.org/10.1016/S0016-7037(99)002653, 1999.

Llyod, R. M.: Oxygen isotope behavior in the SulfateWater System, J. Geophys. Res., 73, 6099-6110, https://doi.org/10.1029/JB073i018p06099, 1968.

Lu, J. -B. Jian, J., Huang, W., Lin, H., Li, J., and Zhou, M.: Experimental and theoretical identification of the $\mathrm{Fe}$ (VII) oxidation state in $\mathrm{FeO}_{4}^{-}$, Phys. Chem. Chem. Phys., 18, 31125-31131, https://doi.org/10.1039/C6CP06753K, 2016.

Mader, M., Schmidt, C., van Geldern, R., and Barth, J. A. C.: Dissolved oxygen in water and its stable isotope effects: A review, Chem. Geol., 473, 10-21, https://doi.org/10.1016/j.chemgeo.2017.10.003, 2017.

Mader, M., Roberts, A. M., Porst, D., Schmidt, C., Trauth, N., van Geldern, R., and Barth, J. A. C.: River recharge versus $\mathrm{O}_{2}$ supply from the unsaturated zone in shallow riparian groundwater: A case study from the Selke River (Germany), Sci. Total Environ., 634, 374-381, https://doi.org/10.1016/j.scitotenv.2018.03.230, 2018.

Marin, B., Nowack, E. C., and Melkonian, M.: A plastid in the making: evidence for a second primary endosymbiosis, Protist, 156, 425-432, https://doi.org/10.1016/j.protis.2005.09.001, 2005.

Meurer, M., Banning, A.: Uranmobilisierung im Helgoländer Buntsandstein - Auswirkungen auf die Brackund Trinkwasserqualität, Grundwasser, 24, 43-50, https://doi.org/10.1007/s00767-018-0408-1, 2019.

Michaud, S. C. and Richardson, C. J.: Relative radial oxygen loss in five wetland plants, in: Constructed Wetlands for Wastewater Treatment, edited by: Hammer, D. A., Lewis Publishers, Chelsea, USA, 501-507, 1989.

Millero, F. J.: The effect of ionic interactions on the oxidation of metals in natural waters, Geochim. Cosmochim. Ac., 49, 54753, https://doi.org/10.1016/0016-7037(85)90046-8, 1985.

Oba, Y. and Poulson, S. R.: Oxygen isotope fractionation of dissolved oxygen during reduction by ferrous iron, Geochim. Cosmochim. Ac., 73, 13-24, https://doi.org/10.1016/j.gca.2008.10.012, 2009a.

Oba, Y. and Poulson, S. R.: Oxygen isotope fractionation of dissolved oxygen during abiological reduction by aqueous sulfide, Chem Geol., 268, 226-232, https://doi.org/10.1016/j.chemgeo.2009.09.002, 2009b.
Park, B. and Dempsey, B. A.: Heterogeneous oxidation of $\mathrm{Fe}(\mathrm{II})$ on ferric oxide at neutral $\mathrm{pH}$ and a low partial pressure of $\mathrm{O}_{2}$, Environ. Sci. Technol., 39, 6494-6500, https://doi.org/10.1021/es0501058, 2005.

Parker, S. R., Poulson, S. R., Gammons, C. H., and DeGrandpre, M. D.: Biogeochemical controls on diel cycling of stable isotopes of dissolved oxygen and dissolved inorganic carbon in the Big Hole River, Montana, Environ. Sci. Technol., 39, 7134-7140, https://doi.org/10.1021/es0505595, 2005.

Parker, S. R., Gammons, C. H., Poulson, S. R., DeGrandpre, M. D., Weyer, C. L., Smith, M. G., Babcock, J. N., and Oba, Y.: Diel behavior of stable isotopes of dissolved oxygen and dissolved inorganic carbon in rivers over a range of trophic conditions, and in a mesocosm experiment, Chem Geol., 269, 22-32, https://doi.org/10.1016/j.chemgeo.2009.06.016, 2010.

Parker, S. R., Gammons, C. H., Smith, M. G., and Poulson, S. R.: Behavior of stable isotopes of dissolved oxygen, dissolved inorganic carbon and nitrate in groundwater at a former wood treatment facility containing hydrocarbon contamination, Appl. Geochem., 27, 1101-1110, https://doi.org/10.1016/j.apgeochem.2012.02.035, 2012.

Parker, S. R., Darvis, M. N., Poulson, S. R., Gammons, C. H., and Stanford, J. A.: Dissolved oxygen and dissolved inorganic carbon stable isotope composition and concentration fluxes across several shallow floodplain aquifers and in a diffusion experiment, Biogeochemistry, 117, 539-552, https://doi.org/10.1007/s10533013-9899-0, 2014.

Parkhurst, D. L. and Appelo, C. A. J.: Description of input and examples for PHREEQC version 3, A computer program for speciation, batch-reaction, one-dimensional transport, and inverse geochemical calculations, Volume book 6, series Techniques and Methods [code], 1-327, available at: https://www.usgs.gov/ software/phreeqc-version-3 (last access: 26 July 2021), 2009.

Pati, S. G., Bolotin, J., Brennwald, M. S., Kohler, H. P. E., Werner, R. A., and Hofstetter, T. B.: Measurement of oxygen isotope ratios $\left({ }^{18} \mathrm{O} /{ }^{16} \mathrm{O}\right)$ of aqueous $\mathrm{O}_{2}$ in small samples by gas chromatography/isotope ratio mass spectrometry, Rapid Commun. Mass Sp., 30, 684-690, https://doi.org/10.1002/rcm.7481, 2016.

Pusch, M.: The metabolism of organic matter in the hyporheic zone of a mountain stream, and its spatial distribution, Hydrobiologia, 323, 107-118, https://doi.org/10.1007/BF00017588, 1996.

Quay, P. D., Wilbur, D. O., Richey, J. E., Devol, A. H., Benner, R., and Forsberg, B. R.: The ${ }^{18} \mathrm{O}:{ }^{16} \mathrm{O}$ of dissolved oxygen in rivers and lakes in the Amazon Basin: Determining the ratio of respiration to photosynthesis rates in freshwater, Limnol. Oceanogr., 40, 718-729, https://doi.org/10.4319/lo.1995.40.4.0718, 1995.

Schwab, R. G.: Die natürliche Radioaktivität der Erdkruste, in: Natürliche und künstliche Strahlung in der Umwelt. Eine Bilanz vor und nach Tschernobyl, edited by: Hosemann, G., and Wirth, E., Erlanger Forschungen Reihe B, Erlangen, Germany, 25-43, 1987.

Schwertmann, U.: Solubility and dissolution of iron oxides, Plant Soil, 130, 1-25, https://doi.org/10.1007/BF00011851, 1991.

Sylvester, P., Westerhoff, P., Boyd, O., and Sengupta, A. K.: Arsen $\mathrm{X}^{n p}$ - A new hybrid sorbent for arsenic removal from drinking water, in: $\mathrm{ACE}^{\prime}$ 05, Proceedings of the AWWA Annual Conference and Exposition, San Francisco, USA, 2005. 
Skinner, B. J.: A Second Iron Age Ahead?, Res. J. Environ. Sci., 3, 559-575, https://doi.org/10.1016/S0166-1116(08)710719, 1979.

Smith, L., Watzin, M. C., and Druschel, G.: Relating sediment phosphorus mobility to seasonal and diel redox fluctuations at the sediment-water interface in a eutrophic freshwater lake, Limnol. Oceanogr., 56, 2251-2264, https://doi.org/10.4319/1o.2011.56.6.2251, 2011.

Stal, L. J.: Cyanobacterial mats and stromatolites, in: The Ecology of Cyanobacteria II: their diversity in space and time, edited by: Whitton, B. A., Springer, Dordrecht, New York, London, 65125, https://doi.org/10.1007/978-94-007-3855-3, 2012.

Stanier, R. Y., Kunisawa R., Mandel, M., and Cohen-Bazire, G.: Purification and properties of unicellular blue-green algae (order Chroococcales), Bacteriol. Rev., 35, 171-205, https://doi.org/10.1128/mmbr.35.2.171-205.1971, 1971.

Swanner, E. D., Mloszewska, A. M., Cirpka, O. A., Schoenberg, R., Konhauser, K. O., and Kappler, A.: Modulation of oxygen production in Archaean oceans by episodes of $\mathrm{Fe}(\mathrm{II})$ toxicity, Nat. Geosci., 8, 126-130, https://doi.org/10.1038/ngeo2327, 126-130, 2015.

Taylor, B. E. and Wheeler, M. C.: Sulfur- and Oxygen-Isotope Geochemistry of Acid Mine Drainage in the Western United States, in: Environmental Geochemistry of Sulfide Oxidation edited by: Alpers, C. N. and Blowes, D. W., American Chemical Society Symposium Series, Washington DC, USA, 481-514, 1993.

Teal, J. M. and Kanwisher, J. W.: Gas Transport in the Marsh Grass, Spartina alterniflora, J. Exp. Bot., 17, 355-361, https://doi.org/10.1093/jxb/17.2.355, 1966.

van Geldern, R. and Barth, J. A. C.: Optimization of instrument setup and post-run corrections for oxygen and hydrogen stable isotope measurements of water by isotope ratio infrared spectroscopy (IRIS), Limnol. Oceanogr. Method., 10, 1024-1036, https://doi.org/10.4319/lom.2012.10.1024, 2012.
Wang, X. and Veizer, J.: Respiration-photosynthesis balance of terrestrial aquatic ecosystems, Ottawa area, Canada, Geochim. Cosmochim. Acta., 64, 3775-3786, https://doi.org/10.1016/S00167037(00)00477-4, 2000.

Wassenaar, L. I. and Koehler, G.: An on-line technique for the determination of the $\delta^{18} \mathrm{O}$ and $\delta^{17} \mathrm{O}$ of gaseous and dissolved oxygen, Anal. Chem., 71, 4965-4968, https://doi.org/10.1021/ac9903961, 1999.

Wassenaar, L. I. and Hendry, M. J.: Dynamics and stable isotope composition of gaseous and dissolved oxygen, Ground Water, 45, 447-460, https://doi.org/10.1111/j.1745-6584.2007.00328.x, 2007.

Weyhenmeyer, G. A., Prairie, Y. T., and Tranvik, L. J.: Browning of Boreal Freshwaters Coupled to Carbon-Iron Interactions along the Aquatic Continuum, PLoS One, 9, e88104, https://doi.org/10.1371/journal.pone.0088104, 2014.

Wilmotte, A., Van der Auwera, G., and De Wachter, R.: Structure of the $16 \mathrm{~S}$ ribosomal RNA of the thermophilic cyanobacterium Chlorogloeopsis HTF (Mastigocladus laminosus HTF') strain PCC75 18, and phylogenetic analysis, FEBS Lett., 317, 96-100, https://doi.org/10.1016/0014-5793(93)81499-p, 1993.

Zhang, Y., Charlet, L., and Schindler P. W.: Adsorption of protons, $\mathrm{Fe}(\mathrm{II})$ and $\mathrm{Al}(\mathrm{III})$ on lepidocrocite $(\gamma$-FeOOH$)$, Colloids Surf., 63, 259-268, https://doi.org/10.1016/0166-6622(92)80247-Y, 1992. 